\title{
Hafıza Ortamından Tüketim Nesnesine Dönüşen Ev
}

\author{
House Transformed From Memory Environment \\ To The Object Of Consumption
}

\section{Ferhat Tekin $^{*}$}

\section{Öz}

Bu makalede bir sosyal mekân olarak ev ve hafıza ilişkisi tüketim bağlamında ele alınmaktadır. Tüketim kültürünün insanların arzularını kışkırtarak onları nasıl çeşitli aralıklarla ev veya konut değiştirmeye zorladığı ve bunun sonucunda eve dair hafızanın nasıl yitirildiğine odaklanılmaktadır. Bu çerçevede öncelikle evin bir sosyal varlık olan insan için taşıdığı öneme değinilmiş; ardından insan-mekân-hafıza ilişkisi bağlamında evin anlamlar, değerler ve ilişkilerin kaydolduğu bir hafıza çerçevesi olarak oynadığı role dikkat çekilmiştir. Son olarak evin tüketim kültürünün etkisiyle nasıl bir meta-göstergeye dönüştüğü ve bunun sonucunda da diğer tüketim nesneleri gibi kullanılıp belli bir süre sonra bir başkasıyla değiştirildiği ve böylece bu yüzer-gezerlik durumuna bağlı olarak ev-hafıza ilişkisinin nasıl silikleştiği serdedilmiştir.

Anahtar Kelimeler: Ev, hafıza, tüketim kültürü, hafızanın silikleşmesi

Doç. Dr. Ferhat Tekin, Necmettin Erbakan Üniversitesi, Sosyoloji Bölümü ferhadtekin@gmail.com

Bu makale iThenticate sistemi tarafından taranmıştır.

Makale Gönderim Tarihi: 31 Aralık 2018 
Ferhat Tekin

\begin{abstract}
In this study, the relationship among house as a social place and memory has been handled within the context of consumption. It is focused on how the consumption culture push people by stimulating their desires to change their houses or residences at certain intervals, so how the memory regarding house is lost in time. Within this frame, it is firstly tough upon the importance that the house carries for individual as a social being and later the role of house within the frame of the memory, where the meanings, values and relationships are recorded, in the context of the relationship among humanplace-memory. Lastly, it was propounded how the house was transformed into a meta-indicator by the effect of consumption culture; so, at the end of it, how it is used for a period and changed with the others and so how the relationship among house and memory is become indistinct due to the situation of amphibiousness.
\end{abstract}

Key Words: House, memory, consumption culture, greying of the memory. 


\section{Giriş}

Toplumsallığın bir iz düşümü olan mekâna dayalı süreçler ve pratikler çok yönlü ve bir o kadar da karmaşıktır. Bu pratikler toplumsal ilişkilerin yeniden üretimi ve dönüşümü süreçleriyle yakından ilgili oldukları için bunları betimlemek ve kullanımları hakkında genellemeler yapmak oldukça elzemdir. Bu bakımdan günümüzde bir mekân olarak evin yeniden üretim ve tüketim süreçlerine bağlı olarak geçirdiği bazı değişim ve dönüşümleri gözlemlemek mümkündür. Dolayısıyla söz konusu süreçlere dair çeşitli veçhelerden bahsedilebilir ki bunlardan biri de ev/konuthafıza ilişkisidir.

Ev sosyal teoride genellikle tüketim ve kentsel dönüşüme bağlı olarak mekânsal ayrışma bağlamında ele alınmıştır. Evin ya da konutun hem sosyal tabakalaşmanın hem de mekânsal ayrışmanın temel göstergelerinden biri olduğuna kuşku yoktur. Ancak tüketim kültürünün insanları sürekli tüketime zorlayarak hafıza kaybına neden olduğu göz önüne alındığında bir mekân olarak evle kurulan ilişkinin de bundan payını aldığını söylemek mümkündür. Dolayısıyla bu metinde tüketim kültürünün insanların arzularını kışkırtarak onları niçin ve nasıl sürekli ev ve konut değiştirmeye zorladığı; bu bağlamda eve dair hafızanın nasıl yitirildiği ve mekânda "yüzer gezer"liğin hafızanın oluşmasını nasıl engellediği ele alınmaktadır. Zira günümüzde çoğunlukla evler ve konutlar artık oturduğumuz için inşa edilmemekte daha ziyade "inşaat endüstrisi" için ticari bir amaç, kullananlar için ise bir meta-gösterge işlevi görmektedir. Bu da özel bir mekân olarak evle kurduğumuz ilişkinin nasıl ters-yüz olduğunu açık bir biçimde göstermektedir. Bu çerçevede içinde bulunduğumuz bu dönemde artık çoğunlukla evlerde değil konutlarda yaşanmakla ve bunların da sıradan bir tüketim nesnesi gibi alınıp satılması ya da değiştirilmesi ile hafıza-ev/konut ilişkisi bu yazıda sorunsallaştırılmaktadır. Bu çalışmayı gerekli kılan diğer bir nokta da tüketim kültürünün unutmaya yol açan yönünün ev / konut bağlamında ele alınması ve dikkatlere sunulmasıdır.

Evin ya da konutun tüketim kültürünün temel nesnelerinden biri haline gelmesinin yeni bir olgu olduğu dikkate alındığında çalış- 
mada yöntemsel olarak bir karşılaştırma yapılmıştır. Bu anlamda tüketim kültürü ve öncesi arasında söz konusu olgu, literatüre de dayanarak mukayese edilmiş ve analizler yapılmıştır. Ayrıca özellikle son yıllarda ev/ konut değiştirme seyrinin gittikçe arttığ1 şehirlerden biri olan Konya'da yapılan uzun süreli gözlemlerden de hareket edilerek bu konuda bazı tespitler ortaya konulmaya çalışılmıştır.

\section{Mekân Olarak Ev: İnsanın Beşiği/Yuvası}

“Mekân nedir?" diye soran H. Lefebvre öncelikle mekâna yönelik ezberleri bozan bir yaklaşımla mekânın ne yaşantının basit bir "çerçeve"si, ne de sadece içine konulan şeyi neredeyse ilgisizce kabul etmek zorunda olan bir biçim ya da kapsayıcıdır diyerek mekânın, "toplumsal morfoloji” olduğunu vurgular. Yani "işlevlere ve yapılara sıkı sıkıya bağlı biçim canlı organizma için neyse, yaşantı içinde odur. Mekânı, içine herhangi bir nesnenin girdiği bir "çerçeve" ya da bir kutu tarzında düşünmek, kuşkusuz ki hatalı bir başlangıçtır" (Lefebvre, 2014: 118). Dolayısıyla mekân, toplumsal ilişkilerin içinde gerçekleştiği fakat aynı zamanda bu gerçekleşmenin kendisine bağlı olduğu ilişkisel bir biçimdir.

Mekânı anlamak istiyorsak "onun simgesel anlamını ve bilişsel süreç aracılığıyla davranış üzerindeki karmaşık etkisini göz önünde bulundurmalıyız" der Harvey. "Mekân hakkında bu görüşü geliştirmenin yararlarından biri, coğrafi ve sosyolojik muhayyileleri kaynaştırma yeteneğine sahip olmasıdır, çünkü elimize toplumsal süreçlerin tüm karmaşıklığını karşılamaya elverişli bilgi olmaksızın toplumsal mekânı tüm karmaşıklığıyla anlamayı bekleyemeyiz" (Harvey, 2013: 40) diyerek aslında bir mekân sosyolojisinin zorunluluğuna dikkati çekmektedir.

John Urry'nin işaret ettiği gibi mekânsal olan, toplumsal olandan ayrılamaz. Bunun nedeni mekânın tek başına genel etkiler taşımaması, sosyal ilişkilere sahne olmasıdır. "Mekânsal ilişkilerin önemi toplumsal nesnelerin özel karakterine bağlıdır." Dolayısıyla "Yalın 'mekân' yoktur, sadece farklı türden mekânlar, mekânsal ilişkiler veya mekânsallaşmalar vardır” (Urry, 2015: 106). Keza 
Lefebvre'nin (2014: 25) dediği gibi mekân kavramı zihinsel olanla kültürel olanı, toplumsalla tarihseli birbirine bağlar.

Mekânın Poetikası adlı eserinde Gaston Bachelard, "yaşam alanımı$\mathrm{zl}$, hayatımızın tüm diyalektikleriyle uyum içinde nasıl doldurduğumuzu, "bir dünya köşesine" her gün nasıl kök saldığımızı gözler önüne sermek gerek"tiğini vurgular. Dolaysıyla Bachelard'ya göre "evimiz bizim dünya köşemizdir, ilk evrenimizdir". Hatta o, "gerçek bir kozmostur" (Bachelard, 1996: 32).

Ev, insan yaşamında, kazanılmış şeylerin korunmasını sağlar, bunları sürekli kılar. Ev olmasaydı, insan dağılıp giderdi. Ev, insanı gökten inen fırtınalara karşı olduğu gibi, yaşantında yaşadığı fırtınalara karşı da ayakta tutar. Aynı zamanda hem beden, hem ruhtur. İnsan varlığının ilk evrenidir. Üstünkörü metafiziklerin öğrettiği gibi, insan "dünyanın ortasına bırakılmadan önce", evin beşiğine yatırılır. Kurduğumuz düşlerde evi her zaman bir büvük beşik olarak düşünürüz. Somut bir metafizik öğreti bu olguyu, bu basit olguyu bir yana atamaz; öyle ki, bu olgu bir değerdir; düş kurmalarımızda tekrar dönüp geldiğimiz önemli bir değer. Varlık, hemen bir değer niteliği kazanır. Yaşam güzel başlar; evin kucağında kapalı, korunmuş ve sıcacık (Bachelard, 1996: 34-35).

Ev ve ontoloji arasında kurulan bu bağ evi içinde yaşanılan basit bir kapalı mekân olmaktan çıkararak ona derin anlamlar kazandırmaktadır. Bu bağlamda Alman filozof Martin Heiddegger'in, oturmak ile var olmak arasında kurduğu ilişki ontolojik açıdan oldukça dikkat çekicidir. "Senin ve benim var olma biçimimiz, bizlerin dünya üzerinde var olmamızın biçimi oturmadır. İnsan olmak demek, dünya üzerinde olumlu olarak var olmak, yani oturmak demektir" (Heidegger, 1996: 68). Dolayısıyla oturmakla yani bir yerde ikamet etmekle var olmayı birbirinden ayrı düşünemeyeceğimiz vurgulanmaktadır ki bunun karşılığı da insanın varlığını sürdürmesi için ihtiyaç duyduğu evdir.

Evin hem insan için bir barınak olduğuna hem de toplumsal yaşamın merkezine yerleştiğini belirten Alver (2013: 63) evi aynı zaman ana rahmine ve anneye benzetir: "Biçimi ve nitelikleri ne 
olursa olsun ev, ana rahmini çağrıştırır. İnsanı sarıp sarmalayan, koruyan, besleyen, tüm tehlikelerden uzak, emin bir yerde büyüten ana rahmi gibidir ev. Evinde olmayı arzular insan, uzun yolculuklardan sonra evine dönmeyi. Evini özler insan ve ancak evinde rahat eder. Eviyle bütünleşir başka hiçbir mekânla bütünleşmediği kadar ve evi ile hem hal olur insan. Anne gibi vazgeçilmez, anne gibi unutulmazdır ev."

Ev, yarı kapalı bir topluluk olan aile adlı grup içinde kurulan kişisel ilişkilerle tamamıyla bütünleşmiş bir görüntü sunar (Baudrillard, 2010: 21). Fakat aynı zamanda bireyin kendisini de temsil eden bir özelliğe sahiptir. $\mathrm{O}$, bilincin, düşünmenin, güvenliğin ve kökleşmenin ilk deneyimlendiği mekân ve benliğin sembolüdür (Cooper, 1974: 138). Dolayısıyla ev aslında birçok yönden sosyopsişik bir varlık olarak insanı sembolize eden bir niteliğe sahiptir. Keza evin en temel özelliklerinden biri de insan elinden çıkmış olması, yani sosyo-kültürel bir yapı olmasıdır. İnsan tarafından inşa edilmesi öngörülen ev, doğrudan kültür unsuru olarak varlık kazanmaktadır (Alver, 2013: 70).

\section{Ev: Bir Hafıza Çerçevesi}

Toplumsal hafıza çalışmalarının öncüsü Maurice Halbwachs, hemen her tür anının, bireyler, gruplar, mekânlar, tarihler, kelimeler ve dil biçimleriyle, muhakemeler ve fikirlerle, yani ait olduğumuz ya da ait olmuş bulunduğumuz sosyal gerçekliklerin tüm maddi ve ahlaki yaşamlarıyla ilişki içinde olduğunu belirtir (2016: 64). Halbwachs bunu ifade etmekle aslında anılarımızın bütünüyle toplumsal olduğunu, toplumsal bağlamı olmayan bir anının ya da anıların mümkün olmadığını vurgulamaktadır.

Diğer taraftan Hafıza Mekânları adlı eserinde Pierre Nora, hafıza ile tarih arasındaki farklara işaret ederek söz konusu ayırımı şu şekilde somutlaştırır: Hafıza, hatırayı kutsallaştırır. Tarih ise hatırayı kapı dışarı eder, onu bayağılaştırır. Hafıza kaynağını bir gruptan alır. Buna karşın tarih herkesin malıdır ya da kimseye ait değildir. Hafıza somuta, mekâna, harekete, imgeye ve nesneye kök salmıştır. Tarih sadece zamansal sürekliliklere, gelişmelere ve nesnelerin ilişkisine bağlıdır. Hafıza mutlaktır, fakat tarih sadece 
göreceli olanı bilir (Nora, 2006: 19). Halbwachs'a göre de tarih, hafıza değildir, çünkü evrensel bir hafıza yoktur, sadece ortak ve gruba özgü, yani "somut kimlikli" hafızanın varlığından söz edilebilir. Yani "her ortak hafıza zaman ve mekânla sınırlı bir gruba aittir" (Akt, Assmann, 2015: 52).

$\mathrm{Bu}$ bağlamda evin hem ortak hem de bireysel hafızayla ilişkisi burada önem arz etmektedir. Ev, duvarlar, kapılar ve çeşitli eşyalardan oluşmuş bir yapıdan; bir barınak veya mekânsal olarak düzenlenmiş gündelik pratiklerden çok daha fazlasını ifade eder. Her şeyden öte "ev, bir temsil aracıdır" ve bu nedenle "hatırlat1cı bir sistem olarak" okunabilir. Aynı zamanda ev, bu mekândaki ilişkileri, gündelik hayatı ve hiyerarşiyi de hatırlatıcı bir niteliğe bürünür. Connerton (2012: 29), evin bu yönden bir muhtıra özelliğine sahip olduğunu vurgular: Ailedeki ayrıcalıklar, doğum sırası gibi şeylerle uyumlu bir şekilde oluşan masa etrafındaki oturma düzeni ile mekânın içine işlenmiş kıdem sıralamalarını hatırlatan bir muhtıradır ev. Keza çeşitli düzenlemeleri, ortak bilgi stokunu, yaşanmışlıkları ve bireylerin hayat hikâyelerini grup belleğinde yeniden canlandıran "bir muhtıradır" ev.

Dolayısıyla ev geçmişe, anılara doğru açılan bir metin gibidir. Nitekim Bachelard'nın (1996: 33) şiirsel ifadesiyle; “...evle ilgili düş kuranın önünde en uzak belleğin ötesinde, düşünülemeyecek kadar eskiye uzanan bir alan açılır. (...) O uzak alanda bellek ve imgelem iç içe geçmiş durumdadır. Her ikisi de birbirinin derinleşmesine karşılıklı katkıda bulunur. Her ikisi de değerler düzeni içinde bir anı ve imge bütünü oluşturur."

Böylelikle ev yalnızca günü gününe, bir tarihsel çizgi boyunca, kendi yaşantımızın anlatısında yaşanır olmaktan çıkar. Düşler aracılığıyla yaşamımızda yer alan farklı yuvalar birbirinin içine girer ve geçmiş günlerin hazinelerini korur. Yeni evimizde aklımıza eski evlerimizin anıları geldiğinde, devinimsiz çocukluğumuzun ülkesine, çok çok eski olan devinimsiz o ülkeye gideriz. Kapalı bir mekânın anıları saklaması, koruması, bu arada bu anıların imge değerlerinin de teslim edilmesi gerekir. Dış dünyaya özgü anılar hiçbir zaman eve özgü olanlarla aynı tınıya sahip olmayacaktır. Evle 
ilgili anıları anımsarken onlara düşsel değerler katarız. (1996: 33-34).

Öte yandan evimiz Halbwachs'ın (2016: 133) dediği gibi mekânsal bir çerçevedir. Fakat geometrik ya da mimari değil. İçinde ilişkilerin, olayların, oyunların, rollerin gerçekleştiği; anlamlar, değerler ve izlenimlerle dolu bir mekânsal çerçeve. Nitekim "içinde yaşanmış bir ev, cansız bir dam altı değildir, içinde oturulan mekân, geometrik mekânı aşar" (Bachelard, 1996: 72) Bir başka ifadeyle bir evde yaşamak, geometrik yapıyı, inşa malzemelerini ve aksesuarları aşan insani değerlerin ve anlamların üretilmesi ve paylaşımasını ifade eder. Hafızada bir eve dair sakladığımız şey, mimari açıdan görebildiğimiz odaların biçimlerinden ve düzeninden çok, oraya dair ilişkiler, anlamlar, değerler ve izlenimlerdir.

Bu bağlamda evler özellikle de geleneksel veya birkaç kuşağın barındığı evler "hafıza ortamları" dır. Zira bu evler yalnızca şimdiki zamana ya da inşa edildiği zaman dilimine değil, bir yandan geçmişe uzanan, bir yandan da uzandığı geçmişe şimdiyi sürükleyen daha geniş bir zaman dilimine aittir. Dolayısıyla söz konusu evler birkaç kuşağı mekânsal olarak birbirine bağladığı gibi önceki kuşakların anılarının aktarıcısı ve onlarla paylaşılan ortak hatıraların yuvalandığı birer hafıza ortamlarıdır. Connerton'ın dediği gibi "evler aile biyografilerinin bir parçasıdır."

Kavramlar ve deneyimler arasındaki ilişkiyi hatırlama figürleri olarak adlandıran Jan Assmann, "zamana ve mekâna bağlılık"1 bu figürleri karakterize eden özelliklerden biri olarak görür. "Zamana ve mekâna bağlılık" çerçevesinde hatırlama figürleri belli bir mekânda cisimleştirilmek ve belli bir zamanda güncelleştirilmek isterler. Zamana dayalı olanı bir tarafa bırakıp mekâna dayalı olana baktığımızda hatıraların yaşanan bir mekâna dayandıklarını fark ederiz. "Aile için ev, kırsal kesimde yaşayanlar için köy (...) mekânsal hatırlama çerçevesini oluşturur. Bu bağ, özellikle uzakta iken "vatan" duygusunu veren çerçevedir. Mekâna, ben'in çevresindeki, ona ait olan şeyler dünyası, onun "maddi çevresi': benliğinin taşıyıcısı ve destekleyicisi olarak ona ait olan şeyler de dâhildir" (Assmann, 2015: 47). Dolayısıyla haf1za mekâna ihtiyaç duyar, bir başka ifadeyle mekâna kaydolarak 
varlık kazanır. "Her bellek tekniğinin ilk aracı mekânlaştırmadır. Mekânın, "hatırlama kültürü"nde, toplumsal ve kültürel bellek pekiştirme tekniklerinde de başrole sahip olması boşuna değildir" (Assmann, 2015: 68). Bu anlamda hafıza zamanı rastgele kaydetmez onu, ancak mekânla bağlantısını kurup somutlaştırarak kaydeder.

Baudrillard, nesneler ve insanların birbirlerine yakın bağlarla bağlanmış olduklarını ve bir "danışıklı dövüş çerçevesinde kendilerine atfedilen duygusal değer sayesinde evde yaşayan bir "kişilik" gibi" algılandıklarını belirtir. Dolayısıyla çocukluk yıllarında yaşanılan evlerin insanların anılarında bu kadar derinlemesine yer etmesinin nedeni hiç kuşkusuz yaşanılan yer olarak adlandırılan mekânın sahip olduğu bu karmaşık yapı olup buraya belli bir şekilde yerleştirilen nesnelere atfedilen simgesel önemdir (Baudrillard, 2010: 22). Nesnelerin anlamlarının ve onlara atfedilen sembolik değerlerin mekânı anımsamada oynadıkları rol elbette kayda değerdir. Ancak mekânsal hafızayı (üstelik bu ev ise) sadece nesnelere atfedilen anlamlara bağlamak hem basit bir indirgemecilik olur hem de mekânının aynı zamanda ilişkilerin, yaşanmışlıkların ve sosyo-kültürel değerlerin mayalanıp onunla bütünleştiğini görmezden gelmek demektir.

Mekân birey için ne kadar çok bağlam içeriyorsa o kadar kalıc1dır. Anılarla, deneyimlerle, algılarla, duyumlarla desteklenmiş bir mekân bellekte ilişkilendirilir, eşleştirilir, yönlendirilir karşılaştırılır ve kodlanır. Bu kodlama uzun süreli belleğe alınma anlamına gelir (Özak ve Gökmen, 2009: 150). Bu bağlamda çocukluk evi, bireyin yaşam sürecinde ilk sosyal mekân deneyiminin oluştuğu uzamdır. Evin farklı odaları, bu köşesi, şu mobilyası, bahçesi, sokağı çocukta genellikle canlı izlenimler uyandırdığı için ve çocuğun zihninde aile bireyleriyle, oyunlarla ve olaylarla ilişkili olduğundan heyecan verici bir değere dönüşür. Bunlar çocuğa sadece bir çerçeve sunmakla kalmaz, aynı zamanda sosyalleşmenin ayrılmaz bir parçası olarak çocuğu besler de (Halbwachs, 2016: 133). Nitekim bu konuda yapılan bir araştırmada (Özak ve Gökmen, 2009) özellikle geniş ailede yetişen bireylerin, mekân hafızalarında ve mekân içerisinde geçen eylemlerinde sosyal ilişkilerin 
yoğun olduğu ve bu ilişkilerin mekâna dair anıları arttırdığı tespit edilmiştir.

Diğer taraftan birey evinden ayrılma ya da evini değiştirme durumunda kaldığında ise adeta "kendisinden bir parça bırakmış gibi gelir ona. Aslında bu çerçeve kaybolduğu için, bu çerçeveyle ilişkili tüm anılar da" (Halbwachs, 2016: 133) kaybolma tehlikesiyle karşı karşıya kalır.

Doğduğumuz eve ait net anıların bizden uzaklaştığı izlenimine kapılırız. ... Yaşadığımız o yerde yaşadığımız şeyleri yaşayıp yaşamadığımızdan kuşkuya düşeriz. Geçmişimiz bir başka yerdedir, yerleri ve zamanları gerçekdışı bir örtü örter. Varlığımızın parçalarını ayrı ayrı işgal ediyormuşuz izlenimine kapilırız (Bachelard, 1996: 81).

Modernleşmeyle birlikte bir mekân olarak klasik ev önemli değişimler geçirmiştir. Özellikle büyük şehirlerde “Ev, tarihsel-şiirsel bir gerçeklikten başka bir şey değildir, folklora, hatta etnolojiye bağlanır. Bu hatıra tebelleş olur, sanatta, şiirde, tiyatroda, felsefede ayak direr. Dahası, 20. yüzyılda inşa edilen korkunç kent gerçekliğinin içinden geçer; nostaljik bir haleyle onu güzelleştirir; eleştiriyi canlandırır. Heidegger kadar Bachelard da -önemi ve etkisi hiç kuşkuya yer bırakmayan yazılarında, Evden heyecanla ve heyecan verici biçimde söz ederler. Ev, hala kutsal, neredeyse dinsel, mutlağa yakın, ayrıcalıklı bir mekân etkisi bırakır" (Lefebvre, 2014: 142). Zira insanın mekânla kurduğu ilişki, çoğu zaman mekânı ve mekânsal unsurları kişileştirmesine ve onlara anlam ve değer atfetmesine kadar uzanabiliyor. "Onları anılarının birer belleği, sırdaşları biliyor. İlk oturduğunuz evi hatırlayınız... Yıllar sonra yolunuz düşüp de gördüğünüzde içiniz bir hoş olmaz mı? Ya da yıllarca oturduğunuz evden bir gün taşınmak zorunda kaldığınızda neler hissedersiniz? Buna ister alışkanlık deyin ister anıların tazelenmesi, sonuçta ikisi de mekânın insan üzerindeki etkisidir" (Göka, 2001: 19). Dolayısıyla ev sadece aile üyelerinin barındığı ve hayata dair her şeyi yaşayıp paylaştıkları bir mekân değil, tüm bunların onunla da paylaşıldığı ve ona sindiği bir sosyo-kültürel mekândır. Bu nedenle bir yerden gitmek zorunda kaldığında yakınlarından ayrılması insana ne kadar zor 
geliyorsa evinden ayrılması da o kadar zor gelir. Çünkü o geride, sadece fiziksel bir yapıyı değil, yaşanmışlıkların içinde anlam kazandığı, her bir köşesinde anıların olduğu ve fiziksel olanın sosyo-kültürel olana dönüştüğü ve hatta simgeselleştiği evini geride bırakmış oluyor. Dolayısıyla ev zamanın ve hızlı değişmenin ezici gücüne ve yok ediciliğine karşı bir sığınak olduğu gibi hafızanın mekânsallaştığ1 yerdir de.

\section{Tüketim Kültürü ve Evin Meta-Göstergeye Dönüşmesi}

Tüketim günümüzde çeşitli mal ve hizmetlerin kullanım değerinin birey tarafından sahiplenilmesi anlayışından çok, bir toplumsal mantığa, kodlara, göstergelere ve toplumsal hiyerarşiye dayanan bir anlamlandırma ve iletişim sürecidir (Baudrillard, 2013: 62). Bu açıdan tüketimi sadece fayda sağlayan iktisadi pratikler olarak değil gösterge, hiyerarşi ve kodları içeren sosyolojik bir olgu olarak ele almak gerekir.

“Tüketim toplumu var olmak için nesnelerine ihtiyaç duyar, daha doğrusu onları yok etmeye ihtiyaç duyar. (...) Bu yüzden yok etme, üretime temel alternatif olarak kalır: Tüketim sadece üretimle yok etme arasındaki aracı bir terimdir. Tüketimde, kendisini yok etmede aşmaya, dönüştürmeye yönelik derin bir eğilim vardır. İşte burası tüketimin anlamını kazandığı yerdir" diye vurgular Baudrillard (2013: 44).

Mekân sorunsalının üretici güçlerin büyümesinden doğduğuna kuşku yoktur. Üretici güçler ve teknikler, mekânın -yerel, bölgesel, ulusal, gezegensel- her düzeyine müdahale etmeyi sağlar (Lefebvre, 2014: 115). 1936 yılında yapılmış bir araştırmaya göre tanınmış birkaç tarihi bina dışında Londra'daki çoğu bina ortalama otuz yıl sonra yenilenir, altmış yıl sonra ise terk edilirdi (Connerton, 2012: 117). Bu yenileme ve ardından gelen terk etme süreci günümüzde çok daha hızlı bir biçimde gerçekleşmektedir. Örneğin on-on beş yıllık bir bina artık "eski" ya da demode olarak görülmektedir. Çağımıza ait bu anlayış aslında keskin bir zihniyet dönüşümüne işaret eder. Nitekim "Bireyler kendilerini, hiçbir iz bırakmayan salt anlık bir şimdiki zaman dizisine indirgerler, hatta izlerinden irrasyonel, gereksiz ve sözcügüun tam anlamıyla moda- 
sı geçmiş diye nefret ettikleri bir şimdiki zaman dizisine. Tıpkı yakın zamanlarda yayımlanmamış her kitabın şüpheli sayılması (...) düşüncesinin zamane insanının sinirini bozması gibi, geçmiş de bir öfke kaynağına dönüşür" (Adorno ve Horkheimer, 2014: 283).

$\mathrm{Bu}$ anlayış kapitalizmin ve tüketim kültürünün işleyiş biçiminden bağımsız değildir. Nitekim Harvey'in (2014: 376) belirttiği gibi "sermayenin içselleşmiş işleyiş kuralları, toplumu kesintisiz olarak dönüştüren, dinamik ve devrimci bir yapıya sahiptir. Süreç, perdeler ve fetişleştirir, büyümeyi yaratıcı yok etme aracılığıyla sağlar." Dolayısıyla yeni ihtiyaç ve istekler yaratarak insanın arzusunu kışkırtır ve sömürür ve böylece hayatın temposunu hızlandırarak mekânları dönüştürür.

“Mekânın tarihi varsa, mekânın dönemlere, toplumlara, üretim tarzlarına ve üretim ilişkilerine göre özgüllükleri varsa, bir kapitalizm mekânı var demektir" der Lefebvre (2014: 148). Bu bağlamda günümüz kapitalizminin ya da üretim-tüketim sisteminin belki de en çok dikkat çeken yönü, mekânsal olarak hemen her sosyal tabakaya hitap eden konut projeleridir. Özellikle günümüzde konut piyasasında meydan gelen patlamayı anlamak için bu piyasadaki aktörlerin oynadıkları rollere dikkat çeken Harvey (2013: 152-154) konut piyasasında bulunan farklı aktör ve grupların konutu kullanım ve değişim değerlerinin birbirinden farklılık gösterdiğini belirtir. Örneğin konutlarda oturanlardan emlakçılara, ev sahiplerinden müteahhitler ve konut inşa sanayisine, mali kurumlardan (bankalar) devlet kurumlarına kadar konut piyasası aslında her bir grubu ya da aktörü farklı amaçlarla motive etmekte ve böylece konutu/evi basit bir tüketim nesnesine veya metagöstergeye dönüştürmektedir.

Günümüzde insanların çeşitli aralıklarla ev değiştirdiklerini sıklıkla gözlemleyebilmekteyiz. Ancak bu, sadece mekân değiştirmekle sınırlı değildir. İnsan ve mekân arasında kurulmuş olan bağın kopmasına da yol açmaktadır. Çoğu zaman yeni bir ev almak aslında gerçek anlamda bir ihtiyaç olmaktan ziyade, tüketim toplumunun ve kültürünün toplum tarafından kabul edilmiş ve onaylanmış bir "kodu"dur. Bu bağlamda Baudrillard'nın (2013: 80) vurguladığ1 üzere, "ihtiyaçlar sistem öğeleri olarak üretilir, 
bir bireyin nesneyle ilişkisi olarak değil." Dolayısıyla ihtiyaçlardan ziyade bir ihtiyaçlar sistemi söz konusudur. Bu da "bireysel düzeyde üretici güçlerin rasyonel biçimde sistematikleşmesinin daha genelleşmiş biçiminden başka bir şey" değildir. O halde esas olan tüketimin mantıksal ve zorunlu olarak üretimin yerine geçmiş olmasıdır.

Evin tüketimle özdeşleşerek kentsel orta sınıf kültürü ve yaşam tarzının en belirleyici ve ayrıştırıcı öğelerinden birisi haline gelmesi, yakın zamanların ürünüdür. Tarihsel bir kurgu olarak 'ideal ev' konfor, rahatlık, saygınlık gibi sembolik çağrışımlarıyla orta sınıf kültürünün odak noktası haline gelmesi (Öncü, 2013: 91) her ne kadar yüz yılı aşkın bir süreyi kapsıyor olsa da tüketim kültürünün bir nesnesi haline gelmesi yeni bir olgudur. Bu bağlamda yeni orta sınıf ve yeni zenginler, başkalarını dışlamak üzere tasarlanmış dışa kapalı gentrification (mutenalaştırma) ve yeniden geliştirme bölgelerini mesken edinmektedirler. Bu mekânlar çevre düzenlemeleri, üsluplaştırılmış biçim ve gündelik hayatın estetikleştirilmesi yönünden yüksek yatırımlara sahne olurlar (Featherstone, 2013: 192). Yeni orta sınıfın estetiğe, hayat tarzına ve yaşamın estetikleştirilmesine yönelik giderek artan ilgisi diğer birçok "yeni" şeyin yanı sıra kendisini en fazla "ideal" ve "yaşanılacak" mekânlar olan kentin "gözde" yaşam alanlarında göstermektedir. Bir örnek vermek gerekirse Konya'da son birkaç yıldır yapılan "Doğaşehir", "Naturapark”, "Zermeram”, "Altın Şehir" vb. gibi kentin yeni "cennetvari" yapıları hem büyüleme hem de üsluplaştırma yoluyla yeni orta sınıfı ve özellikle de kendini mütedeyyin ya da muhafazakâr olarak konumlandıran kesimi cezbetmektedirler. Aslında bu durumu sekülerleşmenin bir başka formu olarak da okumak mümkündür. Zira diğer birçok şey için olduğu gibi bir mekân olarak evin de mütedeyyin insanlar için geçiciliği göz önünde bulundurulduğunda neredeyse aracın amaçtan kurtulduğu ya da ona egemen olduğu söylenebilir.

Ev günümüz tüketim toplumunda kullanım değerinden ziyade bir meta gösterge olarak kullanılmaktadır. Bu anlamda ev, asla kendinde bir nesne olarak tüketilmez, gerek insanları ideal gönderge olarak kendi gruplarıyla ilişkilendirerek, gerekse de üst bir 
statü grubuna referansla onları gruplarından ayırarak fark yaratan bir gösterge olarak güdümlenir. Alver'in (2013: 113) belirttiği gibi özellikle lüks sitelerden ev almak ya da yaşamak ev ihtiyacını aşarak bir tüketim göstergesi olarak işlev görür ve sonuçta bir statü sembolü ve prestij nesnesine dönüşmüş olur.

\section{Evsizlik ya da Hafıza Kaybı}

Evde değer verilen nesneler, birçok kültürde sosyo-ekonomik tabakaya, statüye dayalı maddi göstergeler olmaktan çok aile ve akrabalık bağlarını, değer verilen deneyimleri, önem arz eden yaşanmışlıkları ve anıları somutlaştırır. Böylece evdeki çeşitli görseller, nesneler ve olaylar derinlemesine bir belleğin odağı ve dolayısıyla tüketimci bir kültür ve modanın duyusal aşırıyüklemesinin dişında yer alan bir benlik duygusunun yaratıcısı haline gelir. Ev böylece zaman-mekân sıkışmasının yarattığ1 tahribata karşı korunmaya yarayan bir özel müze niteliğini kazanır. $\mathrm{Bu}$ bağlamda geleneksel insanın evle ilişkisinde belirleyici olan ontolojik bağın, evi standartlaştıran ya da konuta dönüştüren tüketimci anlayışla birlikte kopmuş olduğu söylenebilir. Günümüzde insan "ev"ini artık tahayyül ve tasavvur edememekte, barınacağ1 konutu daha çok paketlenmiş hazır bir ürün olarak edinmektedir (Çelik, 2017: 30). Günümüzde evin bir tüketim nesnesi haline gelmesiyle kimsenin artık ev sahibi olamadığını vurgulayan Kuban'a göre adeta seri üretim biçiminde yapılan apartman blokları, ev ile sahibi arasındaki bağı koparmaktadır. Dolayısıyla artık evlerimizi düşlemiyor sadece satın alıyoruz (Akt. Alver, 2013: 72). Neticede bu süreç hem insan ile ev arasındaki duygusal ve kültürel bağı yok etmekte hem de evi manevi ve psişik boyutundan soyundurmaktadır (Alver, 2013: 73). Bu da insanın evle kurduğu kalıcı/köklü bağın ve hafızanın mekânsallaşması sürecinin yerini sadece gündelik pratiklerin gerçekleştiği bir "yüzer-gezer"lik almaktadır.

Unutma, her ne kadar tüm zamanları kapsayan bir olgu olsa da modernitenin unutma üzerindeki etkisi oldukça dikkat çekicidir. Nitekim Connerton'ın (2012: 15) modernitenin unutturucu etkisine yönelik vurgulayıcı ifadeleri bunu daha da somutlaştırmaktadır. "Modernitenin unutturduğu şeyler oldukça derin, geniştir; 
hayatın ölçüsünün insan olması, aşina olduğumuz toplumsal ilişkilerle örülmüş bir dünyada yaşayıp çalışma deneyimi... Ortak anılara dayanarak hayatın anlamı diye niteleyebileceğimiz şeylerde köklü bir değişimden söz ediyoruz. $\mathrm{O}$ anlam, modernitenin sunduğu yaşam alanlarında meydana gelen yapısal bir dönüşüm ile birlikte erozyona uğruyor. Bu bağlamda mekânsal değişme ile sosyal ve kültürel hafızanın yok olması arasında bir ilişki olduğunu söylemek lazım. Söz konusu hafızanın yitirilmesi elbette sadece günümüze ait bir olgu değildir. İlk olarak geniş ve kalabalık ailelerin barındığı müstakil evlerin yerini alan apartmanlaşma, ardından bunun yerini alan güvenlikli siteler ve nihayet günümüzde revaçta olan içinde yaşam alanlarını da barındıran gösterişli ve büyülü hiper-siteler.

Bu sürecin ilk basamağı olan apartmanlaşmayı betimleyen Korkut Tuna söz konusu dönüşümün mekân-insan ilişkisini nasıl etkilediğine dikkati çeker: apartman yaşantısının hâkim olması sokakları da boşalttı. Sokaklar artık kimsesi olmayan, herkesin malı olan yerlere dönüştü. Bu dönüşümden en büyük zararı çocuklar gördü. Aynı sokakta oturan ve zamanlarının önemli bir bölümünü bu sokaklarda geçirenlerin artık olmadığı bir ortamda çocukların dışarıda, sokakta olmaları mümkün değildir. Böylece çocuklar en büyük sosyalleşme ortamlarını kaybettiler. Dolayısıyla kültür aktarımının ortadan kalktığı bir ortamda kültür erozyonu alabildiğine yaygınlaştı. "Çocuklar artık apartman dairelerinde, belki de olmayan odalarında büyüyeceklerdi." Sonraki kuşaklara kültürün aktarılmasını sağlayan dedeler ve nineler de apartman yaşantısına bağlı olarak yerlerini kaybedince toplumun genleri olan kültürü aktaracak aktörler de önemli ölçüde ortadan kalmış oldu (Tuna, 2013: 401).

Adeta insan ömrünün belleği olan ev, yaşlı birey için başka bir anlam taşır. $\mathrm{O}$, daha çok anılarla süslediği ve gelecek kuşaklara aktarmak istediği güzellikleri, mekânla birlikte düşünmektedir. Zamanın mekânda meydana getirdiği değişiklikler, bir bakıma bu güzelliklerin üzerini örteceğinden, yaşlı yeni durumu kabul etmek istemeyecek ve eskinin devamından yana olacaktır. Bu nedenle kendisine ait dört duvarı onun her şeyidir (Göka, 2001: 89). 
Nitekim onun için çoğu zaman bir odası ve kileri olan evi, çok odalı ve konforlu bir konuttan daha yaşanılabilirdir. ${ }^{1}$

Baudrillard'nın (2013: 16) dediği gibi artık nesneler çă̆ını yaşıyoruz. Yani nesnelerin ritmine ve onların hiç kesintisiz art arda gelişine göre yaşıyoruz. Geçmiş uygarlıkların tümünde dayanıkli nesneler, araçlar veya binalar kuşaklarca insandan daha uzun yaşamışken, bugün onların doğmasını, gelişmesini ve ölmesini izleyen bizleriz. Öyleyse nesnelerin bu hızlı geçişi hafızayı nasıl etkiler? Elbette nesnelerin ivmelerinin bu denli hızlanması hafızanın da zayıflamasına neden olmaktadır. Çünkü üreticinin ve de tüketicinin ömür biçtiği nesne (bu bir ev de olabilir) aslında miadı dolmadığı halde kullanılıp atılmaktadır. Nesnenin miadını belirleyen temel faktör ise demode olduğunun kabul edilmesidir. Dolayısıyla moda olanın, bir bakıma toplumsal hafıza kaybına neden olduğu söylenebilir.

“Toplumsal bellek yitimi bir şeyleşme tipidir, daha doğrusu, şeyleşmenin başlıca biçimidir" diye vurgular Jacoby (1996: 29). Bu şeyleşme biçimi kapitalist sistemin kaçınılmaz bir sonucudur. Zira kâr güdüsünün örgütlediği ve motive ettiği bu sistem yeni mallara yolu açmak için eski malların tasfiye edilmesini gerektirir. Dolayısıyla tüketim toplumunun ideolojik bir dayatması olan "kullan at" tarzı tüketmek günümüzde artık hemen her şey için geçerlidir. Evler kullanılıp atılmıyor elbette fakat kullanılıp "daha iyisi" ya da "yenisi" ile değiştiriliyor.

Bu bağlamda Heidegger, "'inşa etmiş' olduğumuz için oturmuyoruz, oturdukça inşa ediyoruz" (1996: 68) der. Ancak bu mekânsal varoluşa dair ifadenin, içinde bulunduğumuz tüketim kültürüne veya gösterişçi tüketime bağlı olarak anlamını yitirdiğini veya başka bir deyişle yapıbozuma uğradığını söylemek gerekir. Zira artık "inşa etmiş" olduğumuz için oturuyoruz, oturduğumuz ya

1 1990'ların başında Güneydoğu'da "zorunlu göç" sonucunda şehir merkezlerine gelenlerden özellikle yaşlı kuşak öncekinden daha fazla odası bulunan ve daha konforlu olan evlerde yaşamalarına rağmen köyde bir ya da iki odası olan evlerine dair özlemlerini dile getirdiklerine sıklıkla tanık olunmuştur. 
da oturabildiğimiz için değil. Dolayısıyla mekânla, evle kurduğumuz ilişki fazlasıyla değişmiştir.

Bu bağlamda tüketim toplumunda evin iletisi (barınmadan ziyade her ne kadar mekâna dayalı bir sosyal ayrışmaya işaret ediyorsa da) aslında mekânda yüzer-gezer olmaktır. Tüketim ideolojisi bunu gerektirir. Zira bir yere demirlemek onun amacina terstir. Kendini devam ettirebilmektir için arzuları kışkırtarak sürekli "yeni" ve "daha iyi" ev almayı teşvik eder. Dolayısıyla insanların bir yerde sabitlenmesine karşın yüzer-gezer olmalarını sağlamak temel hedeftir. Bu durum günümüzde özellikle orta sınıfın evle (mekânla) olan ilişkisini betimlemektedir. Böylece mekânla kurulan bu yüzer-gezerlik ilişkisi en çok da mekâna dair hafızasızlığ1 gözler önüne sermektedir. Bir başka ifadeyle bu ilişkide bir bellek yitiminden ziyade belleğin oluşamaması söz konusudur. Çünkü mekânla kurulan bu ilişkide mekânsal imge pekişemez ya da oluşsa bile yüzeysel kalır ve süreç içerisinde kaybolur.

Geçmiş ancak kendisi ile ilişki içinde olunduğunda var olabilir (Assman, 2015: 40). Geçmişle ilişkili olmayı sağlamanın yolu ise onun yitip gitmesini engellemektir. İşte bir mekân olarak ev geçmişin kaybolmasını engelleyen ve adeta onun demirlemesini sağlayan bir mekânsal varlıktır. Dolayısıyla ev geçmişle şimdi arasında bağı kurarak hafızayı canlandırır.

Harvey zaman-mekân sıkışmasını mekânın, zaman aracılığıyla yok edilmesi olarak açılar. Günümüzde küreselleşmenin hızına ve yaygınlaşmasına bakıldığında bu açıklama gayet anlamlıdır. Ancak mekânın, "yeni" mekânlar inşa edilerek yok edilmesi de bunun kadar anlamlı bir olgudur. Zira günümüzde eski mekânlar, yeni mekânlar üretilerek yok edilmektedir. Ancak bu durum sadece mekânla sınırlı kalmamaktadır. Zira mekâna yapılan her müdahale aynı zamanda hafızaya da yapılmış olmaktadır (Karaarslan, 2014: 111). Dolayısıyla mekânın yok edilmesi aynı zamanda hafızanın da yok edilmesi anlamına gelir.

Geleneksel evler, modernitenin baş döndürücü hızı, tüketim kültürü ve onun mekâna yansıyan görünümlerinden olan konut projeleri ve inşaat endüstrisinin hızı karşında gittikçe "hafıza 
mekanları"na dönüşmektedirler. Artık hemen her şehirde seyirlik bir "geleneksel kültür evi" bulunmaktadır. Örneğin gezilecek ya da görülecek yerler arasında "Geleneksel Van Evi" ya da "Sille Kültür Evi" yirmi beş-otuz yıl öncesine kadar içinde yaşanılan hafıza ortamları iken şimdi hafıza mekânlarına dönüşmüş bulunuyorlar. Dolayısıyla postmodern tüketim çağında geçmişin kendisi ortadan kaybolmayla karşı karşıyadır. Bu dönemlere ait binaların bugün de varlıklarını sürdürdükleri durumlarda ise, bunlar üzerindeki yenileme ve restorasyon uygulamaları ile bu yapılar tümüyle, simulakra adı verilen ve onlardan çok farklı ve postmodern yapılara benzer bir biçimde, şimdiki zamana dönüştürülmüşlerdir.

Bu bağlamda kültür evleri ya da müze evler insanların geçmişle bağ kurarak hafızalarını canlandırabilirler belki fakat bu hafıza çoğunlukla birey ve aileye özgü bir hafıza değil, genelleşmiş veya anonim bir hafızadır. Bu nedenle kültür evleri/müze evler hafızayla bağ kurmayı değil nostaljik duyguları harekete geçirirler. Dolayısıyla Nora'nın (2006: 17,18) dediği gibi "süreklilik duygusunun kökü mekândadır. Artık hafıza ortamları olmadığı için hafıza mekânları var. (...) Bugün hala hafızamızla yaşıyor olsaydık mekânları ona adama ihtiyacı duymazdık."

Hızla değişen dünyada insanların sosyal ve kültürel bellekleri ile irtibatlarını sağlayabilecek araçsallıklar giderek azalmaktadır (Birekul, 2014: 73). Belki de günümüzde her şeyin hızlı değişmesi ve tüketilmesine bağlı olarak mekânla/evle yeterince bağ kuramadığımız için kolaylıkla ondan vazgeçebiliyor ve unutabiliyoruz. Dolayısıyla evin konuta dönüşmesi ve onun da sürekli değiştirilerek tüketilmesiyle ortaya çıan tam da insan-mekân-hafıza ilişkisinin yok olması veya en hafifinden parçalanıp dağılmasıdır.

\section{Sonuç}

Genelde modern özelde de geç modern (ya da postmodern) çağda yaşamak "katı olan her şeyin buharlaşıp" uçtuğu bir evrenin parçası olmaktır. İnsan, kültür, benlik, anlam, hafıza, mekan ve daha nice fenomen ve olgunun geç modern dönemin tüketim kültürü karşısında bir taraftan yok olduğu diğer taraftan da dönüştürü- 
lerek arz edildiği bir durumla karşı karşıya bulunmaktayız. Bu bağlamda evin konuta dönüşmesi sadece mekânsal ve yapısal bir dönüşümden ziyade evi ev yapan sosyo-kültürel anlam haritalarının da değişerek buharlaştığını söylemek mümkündür.

Günümüzde çoğunlukla evler ve konutlar artık oturduğumuz için inşa edilmiyor. Daha ziyade inşaat endüstrisi için ticari bir amaç, kullananlar için ise bir meta-gösterge işlevi görmektedir. Bu da özel bir mekân olarak evle kurduğumuz ilişkinin nasıl ters-yüz olduğunu apaçık göstermektedir. "Her şeyleştirme bir unutuştur" diyor Adorno ve Horkheimer, (2014: 306). Genelde mekân özelde de ev daha önce hiç olmadığı kadar hem şeyleşti ve fetişleşti hem de dönüştü. Dolayısıyla günümüzde artık çoğunlukla evlerde değil konutlarda yaşanmakla ve bunların da sürekli değiştirilmesi ile hafıza artık ne mekâna kaydolabilmekte ne de varlık kazanmaktadır. Yani sürekli bir unutuş hali söz konusudur. Farklı kuşakların ömürleri artık bir evde geçmiyor ve dolayısıyla birey ve grup hafızasına dönüşmüyor, aksine bir kuşağın ömrü birden çok evde geçiyor ve böylece mekân-hafıza ilişkisi silikleşiyor. Bu beraberinde bir "yüzer-gezerlik" hali içinde olmayı ya da bir yere ait olmamayı getirir. Aslında bu tam da tüketim kültürünün/ sisteminin arzuladığı bir durumdur. Çünkü bir yere, bir durağa veya bir tarza takılıp kalmak onun yapısına ve işleyiş̧ine uymaz. Dolayisıyla mekândan tarza, benlikten kültüre kadar pek çok hususta tüketim sisteminin bireylerde olmasını istediği şey yüzergezer olmak, bir başka deyişle göçebe bir anlayışa sahip olmaktır. $\mathrm{Bu}$ da insani ve insana dair duygu, düşünce, anlam ve ilişkilerin mekânsallaşmasını engellemekte ve böylece bellekte yer edinmesinin altını oymaktadır. Sonuç ise artık her geçen gün "hafıza ortamları" nı yitiren insanların sayısının giderek artmakta olduğu bir toplumda yaşamakta olduğumuzdur. 
Ferhat Tekin

\section{Kaynakça}

Adorno, T. W. ve Horkheimer, Max (2014), Aydınlanmanın Diyalektiği, (Çev: N. Ülner - E. Ö. Karadoğan), İstanbul: Kabalcı Yayıncilik.

Alver, Köksal (2013), Siteril Hayatlar, (3. Bask1), Ankara: Hece Yayınları.

Assmann, Jan (2015), Kültürel Bellek, (Çev: A. Tekin), (2. Baskı), İstanbul: Ayrıntı Yayınları.

Bachelard, Gaston, (1996), Mekânın Poetikası, (Çev: A. Derman), İstanbul: Kesit Yayınc1lik.

Baudrillard, Jean (2010), Nesneler Sistemi, (Çev: O. Adanır, A. Karamollaoğlu), İstanbul: Boğaziçi Üniversitesi Yayınevi.

Baudrillard, Jean (2013), Tüketim Toplumu, (Çev: H. Deliceçaylı, F. Keskin), (6. Bask1), İstanbul: Ayrıntı Yayınları.

Berman Marshall (2013), Katı Olan Her Şey Buharlaşıyor, (Çev: Ü. Altuğ, B. Peker), (16. Baskı), İstanbul: Ankara.

Birekul, Mehmet (2014), “Mekânın Kodlama Gücü: Medeniyetlere Hayat Veren Yapılar", Medeniyet Araştırmaları Dergisi, Cilt: I, Sayı: 2, s. 61-76.

Connerton, Paul (2012), Modernite Nasıl Unutturur, (Çev: K. Kelebekoğlu), İstanbul: Sel Yayıncilık.

Cooper, Clare (1974), "The House as Symbol of the Self", in Desiging for Human Behavior: Architecture and the Behavioral Sciences, ed: J. Lang at al. Stroudsburg, PA: Dowden, Hutchinson \& Ross. pp.130-146.

Featherstone, Mike (2013), Postmodernizm ve Tüketim Kültürü, (Çev: M. Küçük), (3. Baskı), İstanbul: Ayrıntı Yayınları.

Göka, Şenol (2001), İnsan ve Mekân, İstanbul: Pınar Yayınları.

Harvey, David (2013), Sosyal Adalet ve Şehir, (Çev: M. Moralı), (3. Bask1), İstanbul: Metis Yayınları.

Harvey, David (2014), Postmodernliğin Durumu, (Çev: S. Savran), (7. Bask1), İstanbul: Metis Yayınları.

Halbwachs, Maurice (2016), Hafizanın Toplumsal Çerçeveleri, (Çev: B. Uçar), Ankara: Heretik Yayınları. 
Heiddegger, Martin (1996), İnşa Etmek, Oturmak, Düşünmek, (Çev: O. Kunal), Cogito: Kent ve Kültürü, say1: 8, s. 67-70.

Lefebvre, Henri (2014), Mekânın Üretimi, (Çev: I. Ergüden), (2. Bask1), İstanbul: Sel Yayıncılık.

Karaarslan, Faruk (2014), Modern Dünyada Toplumsal Hafıza ve Dönüşümü, Yayınlanmamış Doktora Tezi, Selçuk Üniversitesi Sosyal Bilimler Enstitüsü Konya.

Nora, Pierre (2006), Hafıza Mekânları, (Çev: M. E. Özcan), Ankara: Dost Kitabevi Yayınları.

Urry, John (2015), Mekânları Tüketmek, (2. Baskı), (Çev: R. G. Ö̆̆döl), İstanbul: Ayrıntı Yayınları.

Öncü, Ayşe (2013), “İdealinizdeki Ev” Mitolojisi Kültürel Sınırlan Aşarak İstanbul'a Ulaştı" Mekân, Kültürr, İktidar (iç), (4.Bask1), (Der: A. Öncü, P. Weyland), İstanbul: İletişim Yayınları, s.85103

Özak, Ö. N. ve Gökmen, G. P. (2009). “Bellek ve Mekân İlişkisi Üzerine Bir Model Önerisi" itüdergisi/a: mimarlık, planlama, tasarım, Sayı:8, Cilt:2, 145-155.

Tuna, Korkut (2013), Yeniden Sosyoloji, (2. Basım), İstanbul: İz Yayincilik. 